\title{
PERILAKU CUCI TANGAN DALAM UPAYA MEMUTUS RANTAI INFEKSI
}

\author{
Elsya Fitri Syofian \\ elsyafitrisyofian93@gmail.com
}

\begin{abstract}
ABSTRAK
Infeksi merupakan suatu keadaan yang disebabkan oleh mikroorganisme patogen, dengan/tanpa disertai gejala klinik. Penyebaran kuman atau infeksi biasanya terjadi saat kuman berpindah dari tangan petugas pelayanan kesehatan yang menyentuh pasien. Cuci tangan menjadi salah satu langkah yang efektif untuk memutuskan rantai transmisi infeksi, sehingga insidensi infeksi nosokomial dapat berkurang. Hasil menunjukkan adanya hubungan kepatuhan perawat dalam melaksanakan prosedur cuci tangan enam langkah lima momen untuk memutus rantai infeksi. Faktor yang mempengaruhi kepatuhan perawat dalam melaksanakan prosedur cuci tangan enam langkah lima momen yaitu pengetahuan perawat, usia, tingkat pendidikan, dan masa kerja.
\end{abstract}

Kata kunci: Infeksi, cuci tangan

\section{Latar Belakang}

Pelayanan keperawatan merupakan pelayanan 24 jam dan terus menerus dengan jumlah tenaga keperawatan yang begitu banyak dan berada di berbagai unit kerja rumah sakit. Dalam memberikan pelayanan keperawatan kepada pasien, perawat melakukan prosedur atau tindakan keperawatan yang dapat menimbulkan resiko salah begitu besar (Maria dkk, 2013).
Pada undang undang Nomor 44 tahun 2009 tentang rumah sakit, menyatakan bahwa "setiap pasien mempunyai hak memperoleh keamanan dan keselamatan dirinya selama dalam perawatan di rumah sakit”. Salah satu poinnya yaitu menghindari adanya resiko infeksi nosocomial di rumah sakit, dan mencegah terjadinya kerugian pada pasien yang mengakibatkan kesalahan dari petugas 
medis, pramedis atau non-medis (Depkes RI, 2013).

Infeksi nosocomial atau infeksi yang berhubungan dengan pelayanan kesehatan atau Health Care Associated Infections (HAIs) adalah penyakit infeksi yang pertama muncul dalam waktu antara 48 jam dan empat hari setelah pasien masuk rumah sakit atau tempat pelayanan kesehatan lainnya, atau dalam waktu 30 hari setelah pasien keluar dari rumah sakit. Dalam hal ini termasuk infeksi yang didapat dari rumah sakit tetapi muncul setelah pulang dan infeksi akibat kerja pada petugas di fasilitas pelayanan kesehatan. Rumah Sakit dituntut untuk memberikan pelayanan yang bermutu, efektif dan efisien untuk menjamin Patient safety.

Infeksi rumah sakit di rumah sakit umumnya terjadi melalui tiga cara yaitu melalui udara, percikan dan kontak langsung dengan pasien. Hal ini dapat dicegah melalui perilaku cuci tangan (hand hygiene) petugas kesehatan di rumah sakit (Alvadri, 2014). Teknik dasar yang paling penting dalam pencegahan dan memutus rantai infeksi adalah dengan cara cuci tangan. Mencuci tangan secara tepat merupakan salah satu cara yang dapat dilakukan untuk menurunkan insidensi HAIs. Langkah sederhana namun efektif dalam melindungi pasien dari kejadian infeksi adalah cuci tangan.

Petugas kesehatan mempunyai peran besar dalam rantai transmisi infeksi ini. World Health Organization (WHO) sebagai induk organisasi kesehatan dunia telah mengkampanyekan program keselamatan pasien salah satunya adalah menurunkan risiko HAIs. Cuci tangan menjadi salah satu langkah yang efektif untuk memutuskan rantai transmisi infeksi, sehingga insidensi HAIs dapat berkurang.

\section{Metode}

Metode yang digunakan adalah metode kualitatif. Metode yang berlandaskan teori dari buku, koran, majalah, artikel ilmiah, jurnal print maupun jurnal online, serta e-book yang memuat segala informasi mengenai upaya pemutusan rantai infeksi. Saya mengumpulkan berbagai informasi melaui media-media tersebut untuk mempelajari lebih dalam tentang upaya memutus rantai infeksi. Melalui metode tersebut Saya dapat mengidentifikasi upaya memutus rantai infeksi melalui penerapan cuci tangan. 


\section{Hasil}

Kepatuhan perawat dalam melaksanakan prosedur cuci tangan enam langkah lima momen sangat berpengaruh dala upaya pencegahan memutus rantai infeksi. Infeksi biasanya terjadi saat kuman berpindah dari tangan petugas pelayanan kesehatan yang menyentuh pasien. Karenanya WHO menerapkan lima momen Hand Hygiene untuk petugas kesehatan adalah dengan melakukan cuci tangan:

1. sebelum bersentuhan dengan pasien

2. sebelum melakukan prosedur bersih/steril,

3. setelah bersentuhan dengan cairan tubuh pasien resiko tinggi,

4. setelah bersentuhan dengan pasien,

5. setelah bersentuhan dengan lingkungan sekitar pasien

Cuci tangan merupakan kegiatan yang efektif dalam mencegah serta memutus rantai infeksi karena tujuan dari mencuci tangan itu sendiri adalah untuk menghilangkan mikroorganisme yang ada ditangan, mencegah penularan infeksi, menjaga dalam kondisi steril, serta memberikan perasaan segar dan bersih. Meskipun perawat yang memberikan pelayanan 24 jam kepada pasien, tetapi prosedur mencuci tangan harus dilakukan oleh tenaga kesehatan lainnya seperti dokter, bidan, seluruh staff rumah sakit, dan lainlain demi menghindarinya kejadian infeksi.

Terdapat beberapa faktor yang mempengaruhi keberhasilannya memutus rantai infeksi dalam melaksanakan prosedur cuci tangan enam langkah lima momen. Yaitu seperti pengetahuan perawat mengenai pentingnya cuci tangan, dengan pengetahuannya akan menimbulkan sikap dan akhirnya menyebabkan perawat akan berperilaku yang didasarkan pada kesadaran pentingnya mencegah atau memutus rantai infeksi melalui cuci tangan. Pengetahuan yang baik juga didasari oleh usia, semakin bertambah usia seseorang maka akan semakin berkembang pola pikir seseorang tersebut.

Selain itu tingkat pendidikan juga berpengaruh terhadap kepatuhan perawat dalam mencuci tangan. Semakin tinggi pendidikan seseorang akan semakin mudah untuk menerima informasi, dan pada akhirnya makin banyak pula pengetahuan yang dimiliki oleh perawat tentang pencegahan dan juga pemutusan rantai infeksi dengan perilaku mencuci tangan. 
Lama masa bekerja perawat juga mempengaruhi terhadap kepatuhan perawat mencuci tangan, perawat yang sudah cukup

\section{Pembahasan}

Perawat adalah tenaga medis yang selama 24 jam bersama dengan pasien yang dirawat di rumah sakit. Peran perawat sangat besar dalam proses penyembuhan pasien. Perawat dituntut mempunyai pengetahuan, ketrampilan dan sikap yang baik selama merawat pasien. Kepatuhan perawat dalam melaksanakan prosedur tetap tindakan keperawatan, termasuk didalamnya prosedur mencuci tangan, menjadi salah satu penentu keberhasilan pencegahan infeksi nosokomial (Costy P, 2013).

Infeksi merupakan suatu keadaan yang disebabkan oleh mikroorganisme patogen, dengan/tanpa disertai gejala klinik. Infeksi Terkait Pelayanan Kesehatan (Healthcare Associated Infections) yang selanjutnya disingkat HAIs merupakan infeksi yang terjadi pada pasien selama perawatan di rumah sakit dan fasilitas pelayanan kesehatan lainnya dimana ketika masuk tidak ada infeksi dan tidak dalam masa inkubasi, termasuk infeksi dalam rumah sakit tapi muncul setelah pasien pulang, juga infeksi karena pekerjaan pada petugas rumah sakit dan tenaga kesehatan lama bekerja akan memiliki pengetahuan yang baik tentang prosedur mencuci tangan.

terkait proses pelayanan kesehatan di fasilitas pelayanan kesehatan (Depkes RI No.27)

Infeksi nosokomial dapat dicegah dengan $10 \%$ lingkungan dan $90 \%$ perilaku. Salah satu perilaku untuk mencegah maupun memutus penyebaran penyakit dari orang ke orang atau dari peralatan ke orang dapat dilakukan dengan meletakkan penghalang diantara mikroorganisme dan individu (pasien atau petugas kesehatan). Penghalang dapat berupa upaya fisik yaitu cuci tangan.

Penyebaran kuman atau infeksi biasanya terjadi saat kuman berpindah dari tangan petugas pelayanan kesehatan yang menyentuh pasien. Cuci tangan menjadi salah satu langkah yang efektif untuk memutuskan rantai transmisi infeksi, sehingga insidensi infeksi nosokomial dapat berkurang. Pencegahan melalui pengendalian infeksi nosokomial di rumah sakit ini mutlak harus dilaksanakan oleh seluruh jajaran managemen rumah sakit meliputi para dokter, bidan, perawat dan lainlain (Darmadi, 2008). 
Pada tahun 2009, WHO mencetuskan global Patient Safety a World Alliance for Safer Health Caredengan Save Lives Clean You Hands, yaitu merumuskan inovasi strategi penerapan Hand Hygiene untuk petugas kesehatan dengan for Hand Hygiene adalah melakukan cuci tangan:sebelum bersentuhan dengan pasien, sebelum melakukan prosedur bersih/steril, setelah bersentuhan dengan cairan tubuh pasien resiko tinggi, setelah bersentuhan dengan pasien, setelah bersentuhan dengan lingkungan sekitar pasien (WHO, 2009).

Menurut pendapat Perry \& Potter (2005), mencuci tangan salah satu kewajiban dari tenaga kesehatan yaitu dengan mencuci tangan merupakan teknik dasar yang paling penting dalam pencegahan dan pengontrolan infeksi nosokomial. Perawat dapat memperhatikan apakah mereka sudah melakukan prosedur cuci tangan yang baik dan benar, karena perawat adalah petugas kesehatan yang paling rentan menjadi perantara terjadi infeksi (Nita,dkk 2012).

Tujuan dilakukannya cuci tangan adalah mengangkat mikroorganisme yang ada di tangan, mencegah infeksi silang (cross infection), menjaga kondisi steril, melindungi diri dan pasien dari infeksi, memberikan perasaan segar dan bersih.
Mencuci tangan selain sebagai pencegahan sebuah penyakit masuk ke dalam tubuh, cuci tangan juga berperan sebagai pemutus rantai penularan sebuah penyakit. Cara mencuci tangan yang baik dan benar bukan hanya wajib dikuasai oleh anak-anak atau orang dewasa, tetapi sangat penting bagi tenaga kesehatan. Para professional di bidang kesehatan seperti dokter dan perawat wajib mengetahui teknik bagaimana seharusnya mencuci tangan agar benar-benar menghilangkan kuman atau bakteri dari permukaan tangan.

Cuci tangan harus dilakukan dengan benar sebelum dan sesudah melakukan tindakan perawatan meskipun memakai sarung tangan atau alat pelindung lain untuk menghilangkan atau mengurangi mikroorganisme yang ada di tangan sehingga penyebaran penyakit dapat dikurangi dan lingkungan terjaga dari infeksi. Kegagalan menjalankan kebersihan tangan merupakan penyebab utama infeksi nosokomial (infeksi yang terjadi akibat pelayanan kesehatan di rumah sakit setelah 48 jam atau lebih). Pengendaian infeksi menjadi salah satu faktor penting dalam pengelolaan Rumah Sakit. Hendaknya tenaga kesehatan melakukan enam langkah lima momen hand hygiene dengan demikian pengendalian penyakit infeksi dengan cara 
mencuci tangan sangat penting dilakukan di rumah sakit untuk mencegah serta memutus rantai infeksi.

Mencuci tangan merupakan salah satu penerapan universal precaution pada perawat. Seorang perawat dikatakan professional, jika memiliki pengetahuan keterampilan serta memiliki sikap professional sesuai kode etik profesi. Pengetahuan perawat dapat terus meningkat apabila rumah sakit dapat terus meningkatkan kemampuan dengan berbagai pelatihan dan edukasi berkesinambungan bagi seluruh karyawan pada semua aspek pencegahan infeksi adalah dengan menerapkan cuci tangan.

Dalam kasus ini, dibutuhkan kepatuhan perawat untuk menjalankan perilaku cuci tangan untuk mencegah ataupun memutus rantai infeksi. Pengetahuan perawat juga menjadi salah satu faktor dalam patuhnya menjalankan prosedur cuci tangan enam langkah lima momen. Sehingga dengan pengetahuannya akan menimbulkan sikap dan akhirnya menyebabkan individu atau kelompok akan berperilaku yang didasarkan pada kesadaran dan kemauan individu yang bersangkutan. Seperti penelitian yang dilakukan oleh Jamaluddin (2012) dimana didapatkan peningkatan pengetahuan karena diadakannya sosialisasi penyuluhan cuci tangan untuk perawat, sebelum dilakukan sosialisasi hanya sekitar $80 \%$ dan setelah dilakukan sosialisasi meningkat menjadi $100 \%$ pengetahuan perawat tentang pentingnya cuci tangan dan prosedur cuci tangan.

Pengetahuan perawat yang baik juga dipengaruhi beberapa faktor. Contohnya seperti tingkat pendidikan. Menurut teori Mubarak (2011) mengatakan bahwa tingkat pendidikan berarti bimbingan yang diberikan oleh seseorang terhadap perkembangan orang lain menuju ke arah suatu cita-cita tertentu. Pendidikan adalah salah satu usaha untuk kepribadian dan kemampuan di dalam dan di luar sekolah dan berlangsung seumur hidup. Semakin tinggi pendidikan seseorang semakin mudah pula untuk menerima informasi, dan pada akhirnya makin banyak pula pengetahuan yang dimiliki oleh perawat tentang pencegahan dan juga pemutusan rantai infeksi dengan perilaku cuci tangan.

Usia juga menjadi salah satu faktor yang mendasari pengetahuan seseorangg, karena semakin bertambahnya usia maka semakin berkembang pula daya tangkap dan 
pola pikir seseorang sehingga pengetahuan yang diperoleh semakin baik.

Faktor lain yang memengaruhi kepatuhan perawat untuk melaksanakan cuci tangan enam langkah lima momen adalah masa kerja, dimana hal tersebut mempengaruhi pengetahuan perawat tentang cuci tangan. Perawat yang sudah memiliki masa kerja cukup lama akan lebih mengetahui tentang cuci tangan dibandingkan dengan perawat yang baru saja masuk ke dunia kerja.

Sejauh ini sudah cukup banyak perawat yang patuh melakukan prosedur cuci tangan demi memutus rantai infeksi. Namun masih ada beberapa perawat yang belum melakukan prosedur cuci tangan dengan baik dan benar. Untuk meningkatkan pengetahuan petugas kesehatan mengenai cuci tangan diperlukan pelatihan mengenai pentingnya cuci tangan dan manfaatnya. Kesadaran dari petugas kesehatan juga dapat mempengaruhi perilaku dalam cuci tangan. Sedangkan untuk perilaku cuci tangan yang masih buruk, dapat dipengaruhi oleh kurangnya fasilitas cuci tangan yang baik dan berfungsi, seperti wastafel, kran air, sabun cuci tangan, dan handuk atau tisu kering.

\section{Penutup}

Menerapkan prosedur cuci tangan enam langkah lima momen merupakan faktor yang cenderung dominan dan berpengaruh dalam upaya memutus rantai infeksi. Karena cuci tangan yang baik, juga akan membawa dampak positif terhadap diri perawat dan pasien. Sebaliknya jika perawat tidak melakukan cuci tangan yang baik maka akan berdampak negative bagi perawat dan pasien, seperti terkena salah satu infeksi nosokomial. Dimana dari hasil penelitian yang didapatkan semakin sering perawat melakukan prosedur mencuci tangan enam langkah yang benar semakin sedikit peluang terjadinya infeksi nosokomial, begitu juga sebaliknya semakin perawat tidak melakukan cuci tangan yang baik maka semakin besar peluang terjadinya infeksi nosokomial. 


\section{Daftar Pustaka}

Basuki, D., \& Nofita, M. (2017). Hubungan

Kepatuhan Cuci Tangan Enam Langkah

Lima Momen Perawat dengan Kejadian

Phlebitis di RSUD DR. Wahidin Sudiro

Husodo Mojokerto. Jurnal Keperawatan, 6(1), 47-53.

Delima, M., Andriani, Y., \& Gustinawati.

(2018). Penerapan Cuci Tangan Five

Momen Dengan Angka Kejadian Infeksi

Nosokomial. Prosiding Seminar Kesehatan

Perintis, 1(2), 8-16.

Herman, M. J., \& Handayani, R. S. (2016).

Sarana dan Prasarana Rumah Sakit

Pemerintah dalam Upaya Pencegahan dan

Pengendalian Infeksi di Indonesia. Jurnal

Kefarmasian Indonesia, 6(2), 137-146.

Rabbani, I., Pateda, V., Wilar, R., \&

Rampengan, N. H. (2014). Hubungan

Pengetahuan Terhadap Perilaku Cuci

Tangan Petugas Kesehatan di Bagian Ilmu

Kesehatan Anak Blu RSUP Prof DR RD

Kandou Manado. Jurnal E-Clinic, 2(1).

Rikayanti, K. H., \& Arta, S. K. (2014).

Hubungan Tingkat Pengetahuan dengan

Perilaku Mencuci Tangan Petugas

Kesehatan di Rumah Sakit Umum Daerah

Bandung Tahun 2013. Community Health, 2(1), 21-31.
Riyadi, S., \& Kurnianti, R. (2018). Efektivitas Penerapan Cuci Tangan Disinfeksi dalam Meningkatkan Kepatuhan Pencegahan dan Pengendalian Infeksi Silang di Laboratorium Pelayanan Kesehatan Gigi dan Mulut. Jurnal Bahan Kesehatan Masyarakat, 2(2), 139-146.

Sani, F. N., \& Pratiwi, R. M. (2017). Hubungan Motivasi Perawat dengan Tingkat Kepatuhan Melakukan Cuci Tangan. Profesi, 14(2), 11-18.

Sari, Prafita Sari. (2019). Efektifitas Kepatuhan Perawat dengan Kejadian Infeksi Post OP di Ruang Mawar RSI Nashrul Ummah Lamongan. Medica Majapahit, 11(2), 29-35.

Simamora, R. H. (2019). Pengaruh Penyuluhan Identifikasi Pasien dengan Menggunakan Media Audiovisual Terhadap Pengetahuan Pasien Rawat Inap. Jurnal Keperawatan Silampari, 3(1), 342-351.

Wulandari, Y., \& Sholikah, S. (2017). Pengetahuan dan Penerapan Five Moments Cuci Tangan Perawat di RSUD Sukoharjo. Gaster Jurnal Kesehatan, 15(1), 18-27. 
